\title{
Editorial
}

\section{6: ¿Un año especial e inolvidable?}

$\mathrm{E}$ 1 Presidente de la República así lo prometió al pueblo salvadoreño en su discurso de fin de año. Cuenta para ello, ya de seguro, con la llegada de su Santidad Juan Pablo II y con el aniversario número cuatrocientos cincuenta de San Salvador. Dos acontecimientos que, esperamos, no los conciba como planificación del ejecutivo. Pero para que no lleguemos a olvidar su propia gestión gubernamental nos ofreció, también en esa oportunidad, "más" de todo, así en general, en un ambiente navideño en el que no se escatiman las muestras de buenos deseos y sueños felices.

Todo parece indicar, no obstante, que 1996 llegará a ser inolvidable pero por otras razones que, eso sí, podrán atribuirse a la actuación u omisión del gobierno. Entre ellas están los graves obstáculos que enfrentan el proceso de democratización de El Salvador y el de mejoramiento social y económico de importantes sectores productivos, en especial los de mayor vulnerabilidad en este proceso de transición política y económica. Problemas frente a los cuales el Estado no logra articular una respuesta eficiente mientras adquieren crecimiento y arraigo.

Los actores del conflicto social en ciernes son varios y de variada naturaleza. Los desmovilizados no son los únicos descontentos en el país, quizás los más activos y estrepitosos. También existen empresarios agrícolas e industriales amenazados por la bancarrota económica y social que ven con muy poco entusiasmo el futuro al reconocer que las políticas crediticias son restrictivas para muchos de ellos, que hay poca atención gubernamental para su reconversión y pocos programas de fomento e incentivación para integrarse a la globalización. Cada vez más, los obreros de las industrias tradicionales amenazadas por la ruina, las del "modelo anterior" (como dicen al modelo de sustitución de importaciones los grandes empresarios que se transnacionalizan ) están siendo lanzados al desempleo permanente, debido a su edad y habilidades productivas que no califican 
en el sector maquila que es la que generará nuevos empleos.

Los empleados públicos que pierden su empleo por el 471 y por las privatizaciones de las empresas públicas se insertarán en la vulnerabilidad de la pobreza que no logra ser reducida a pesar de las millonarias campañas del FIS/ Secretaría de Reconstrucción y ONGs de todo tipo. Todo esto en nombre de la modernización, en especial la del Estado, y el progreso que ningún funcionario y/o gran empresario logran explicar cómo se realizará y cómo beneficiará a la población salvadoreña, en especial al sector que ha sido afectado directamente por los despidos actuales. Los desmovilizados no han logrado insertarse después de cuatro años a circuito económico alguno y la improductividad y la desorganización son el producto de cuatro años de esperanzas, trabajo y gastos. Por otra parte, en la actualidad se le pasa la cuenta a los cooperativistas que en un tiempo se les llamó "beneficiarios" de la Reforma Agraria, quienes arruinados y desesperanzados pierden sus tierras codiciadas ahora por empresarios turísticos o agroindustriales.

Los asalariados se angustian cada vez más en la medida que el nuevo año avanza. El movimiento obrero está dividido y en cierto modo maniatado. Son muy pocos los logros y victorias obreras en los años de la paz y no han podido defenderse de las amenazas del desempleo, la indetenible pérdida del poder adquisitivo, la inflación y la flexibilización de la aplicación de las leyes laborales. Los campesinos olvidados continúan refugiándose en las siembras del autoconsumo sin esperanzas de que existan programas de recuperación del agro y de la producción de alimentos que pierden importancia frente a las importaciones de los productos agropecuarios de diversa índole. La descapitalización, el endeudamiento legal e ilegal, la mora, etc., son realidades ante las cuales aún no hay propuestas para su reversión y superación.

Frente a este panorama potencialmente cargado de conflicto y violencia el gobierno se autocomplace con medidas macroeconómicas que han hecho crecer la economía, aunque no tanto como la estimaban los mismos economistas estatales ni como lo necesita el crecimiento de la población y sus necesidades siempre diferidas. Crecer no basta, entonces. A nivel de pueblo esto no tiene significación alguna. Anteriormente también han existido muchos años de crecimiento continuo y tampoco se terminó con la pobreza ni se mejoró sustancialmente la vida de la población. Se requiere de medidas reales que orienten, en forma simultánea y armónica, hacia el desarrollo, la equidad y la distribución. De lo contrario el conflicto crecerá hasta los límites que ya conocemos y que nadie desea su repetición y vivencia.

Ante este abandono de amplios espacios productivos no es extraño el ambiente de inseguridad ciudadana. La violencia anterior se ha transformado en otra de similares consecuencias para la población. El crimen, la delincuencia, la corrupción pública y privada, organizados o no, imperan en las calles, institucio- 
nes y empresas en todo el territorio nacional. Los negocios ilegales e inmorales se han vuelto no sólo formas de enriquecimiento rápido sino en formas únicas de subsistencia para sectores desesperados y marginados completamente de la sociedad. El indefenso ciudadano de a pie muere, es herido, golpeado, violado, robado, acorralado por esta violencia cada día más poderosa.

La respuesta de la ciudadanía ha sido impactante: la desconfianza en la política y en lo político. Hay en la actualidad una desconfianza bastante generalizada en las instituciones estatales, lo mismo en las de justicia que en la presidencia de la república, en la asamblea legislativa que en los ministerios públicos, en los partidos políticos que en la PNC —que cada vez más muestra hábitos y comportamientos que recuerdan el pasado policial y que se distancia velozmente de la ciudadanía-, o que en los funcionarios, etc. Así lo muestran las encuestas de opinión y también lo refleja la ausencia ciudadana tan marcada en las elecciones del pasado.

No es agradable prever catástrofes ni pretendemos que los señalamientos que aquí se hacen las anticipen, perc se hace necesario reflexionar sobre esta concentración de hechos y procesos que, sin darles la atención debida y sin proyectos que lleven a desmontar o solucionar estos conflictos, provocarán situaciones y momentos de gran peligro para la estabilidad y la gobernabilidad democrática, para el verdadero desarrollo del país. El despido masivo de trabajadores, la desregularización laboral, la ruina y desaparición de medianos y pequeños empresarios, el subempleo y depauperización creciente junto a una delincuencia imparable, a la impunidad de la corrupción y la arbitrariedad, a la ineficiencia de los órganos del estado, a la desafección política ciudadana, al ausentismo electoral, etc., están aunándose y amalgamándose para gestar conflictos serios en el futuro inmediato. Podría pensarse que muchos de estos rasgos sean los síntomas de una venidera crisis de autoridad o de una crisis motivacional social que vuelva más difícil la recomposición de la sociedad salvadoreña.

El proceso de democratización tampoco ha avanzado muy bien que digamos. Una democracia robusta requiere de partidos dinámicos y fuertes. Todos los partidos, de una u otra forma, están en crisis, divididos o muy debilitados. Las reformas electorales para mejorar y ampliar la participación ciudadana avanzan muy despacio y no hay forma de mejorar las instituciones, los mecanismos y las normativas electorales. La innovación representativa está cerrada y se seguirá funcionando con formas de representación de comienzos de siglo. Las próximas elecciones se realizarán en marcos legales y representativos del pasado que han permitido que los cementerios tengan una calidad de circunscripción electoral al contener el actual padrón electoral varios miles de muertos que, como después de cada proceso electoral puede comprobarse, continúan ejerciendo su voto ciudadano.

La democracia es comunicación y expresión, es vivir en lo público y regular 
lo privado. No obstante, en los últimos meses la ley del silencio es de nuevo impulsada por el estado y el partido de gobierno. Los "sin voz" pierden sus canales de expresión con gran celeridad y como ejemplo pueden citarse el cierre y secuestro de instrumentos y aparatos de las radios locales; la desaparición de un periódico independiente por no tener la confianza de los publicistas y grandes empresas que se anuncian; la ley mordaza que aún pende sobre los medios de comunicación; la desaparición de las homilías que todos los domingos señalaban injusticias y desigualdades, las prohibiciones y amenazas a programas radiales y televisivos que de alguna manera presionaban al estado y al partido de gobierno, el cual aumenta su participación y decisión en el orden estatal. Los mismos partidos políticos han mostrado no estar preparados para manejar el disenso al expulsar a las facciones que no están de acuerdo con los grupos fuertes de dirección y han protagonizado divisiones interminables a nombre de fundamentos y principios.

Aún no se logra consensuar una agenda para la democracia y varios analistas han señalado, desde hace algunos años, el peligro de enrumbarse hacia el "autoritarismo blando" que el famoso Fukuyama, el del "fin de la historia", descubre como necesario para el desarrollo económico y social en los dragones, tigres, leones del limitado zoológico del Asia Oriental (la nueva Meca, la nueva ruta de cruzadas y espacio de peregrinaje de nuestros funcionarios, grandes empresarios, comunicadores, publicistas e intelectuales). La "dictablanda", como le han llamado también los estudiosos de la transición latinoamericana, ya tiene defensores en nuestros periódicos y en la opinión pública se ha comenzado a generar "la necesidad" de un personaje "fuerte" en la política. El Estado, la policía, la justicia, los funcionarios se están tornando duros, mientras las instituciones y organismos de los sectores populares se vuelven débiles.

La democracia, no hay duda, requiere de un fortalecimiento que sólo puede provenir de sí misma, de los auténticos demócratas. Como aquella imagen del jinete que habiendo caído en arenas movedizas, y sin posibilidad de ayuda desde afuera del pozo, sólo pudo salvarse tirando él mismo de su propio cabello hacia arriba, con sus propias manos y brazos, hasta hacer salir al caballo y jinete a orilla segura.

La combinación de la incertidumbre económica, del desempleo, la ruina empresarial, el déficit o la lentitud del proceso de democratización, la falta de oportunidades económicas, la inseguridad ciudadana, la impunidad y el empobrecimiento pueden desembocar en un "especial e inolvidable" 1996. 